\title{
T cells conditioned with MDSC show an increased anti-tumor activity after adoptive $\mathrm{T}$ cell based immunotherapy
}

\author{
Patrick L. Raber ${ }^{1}$, Rosa A. Sierra², Paul T. Thevenot ${ }^{3}$, Zhang Shuzhong ${ }^{2}$, Dorota D. \\ Wyczechowska ${ }^{4}$, Takumi Kumai ${ }^{2}$, Esteban Celis ${ }^{2}$ and Paulo C. Rodriguez ${ }^{2}$ \\ ${ }^{1}$ Adaptive Biotechnologies, Seattle, WA, USA \\ ${ }^{2}$ Georgia Regents University Cancer Center, Augusta, GA, USA \\ ${ }^{3}$ Institute of Translational Research, Ochsner Medical Center, New Orleans, LA, USA \\ ${ }^{4}$ Stanley S. Scott Cancer Center, Louisiana State University Health Sciences Center, New Orleans, LA, USA \\ Correspondence to: Paulo C. Rodriguez, email: PauRodriguez@gru.edu \\ Keywords: adoptive T cell transfer immunotherapy (ACT), myeloid-derived suppressor cells (MDSC), mammalian target of rapamy- \\ cin (mTOR), central memory $T_{\text {cells }}\left(T_{C M}\right)$, stem cell memory $T_{\text {cells }}\left(T_{S C A}\right)$, Immunology and Microbiology Section, Immune response, \\ Immunity \\ Received: October 20, $2015 \quad$ Accepted: March 14, $2016 \quad$ Published: March 19, 2016
}

\section{ABSTRACT}

The success of adoptive T cell-based immunotherapy (ACT) in cancer is limited in part by the accumulation of myeloid-derived suppressor cells (MDSC), which block several $T$ cell functions, including $T$ cell proliferation and the expression of various cytotoxic mediators. Paradoxically, the inhibition of $\mathrm{CD8}^{+} \mathrm{T}$ cell differentiation into cytotoxic populations increased their efficacy after ACT into tumor-bearing hosts. Therefore, we aimed to test the impact of conditioning $\mathrm{CD}^{+} \mathrm{T}$ cells with MDSC on their differentiation potential and ACT efficacy. Our results indicate that MDSC impaired the progression of $\mathrm{CDB}^{+} \mathrm{T}$ cells into effector populations, without altering their activation status, production of IL-2, or signaling through the $\mathrm{T}$ cell receptor. In addition, culture of $\mathrm{CDB}^{+} \mathrm{T}$ cells with MDSC resulted in an increased ACT anti-tumor efficacy, which correlated with a higher frequency of the transferred T cells and elevated IFNy production. Interestingly, activated $\mathrm{CD} 62 \mathrm{~L}^{+} \mathrm{CD8}^{+} \mathrm{T}$ cells were responsible for the enhanced anti-tumor activity showed by MDSC-exposed $\mathrm{T}$ cells. Additional results showed a decreased protein synthesis rate and lower activity of the mammalian/ mechanistic target of rapamycin (mTOR) in T cells conditioned with MDSC. Silencing of the negative $\mathrm{mTOR}$ regulator tuberous sclerosis complex-2 in $\mathrm{T}$ cells co-cultured with MDSC restored mTOR activity, but resulted in $\mathrm{T}$ cell apoptosis. These results indicate that conditioning of $\mathrm{T}$ cells with MDSC induces stress survival pathways mediated by a blunted mTOR signaling, which regulated $T$ cell differentiation and ACT efficacy. Continuation of this research will enable the development of better strategies to increase ACT responses in cancer.

\section{INTRODUCTION}

Adoptive $\mathrm{T}$ cell-based immunotherapy (ACT) to specifically eliminate tumor cells, or to prevent their recurrence, represents an emerging treatment for patients with various malignancies $[1,2]$. The success of ACT is significantly limited by the inhibitory inflammatory microenvironment present in tumors [3]. Myeloid-derived suppressor cells (MDSC), a subset of myeloid precursors, are primary components of the tumor milieu and key negative regulators of the function of $\mathrm{T}$ cells, natural killer (NK), and dendritic cells $[4,5]$. MDSC inhibit T cell immunity through various mechanisms, including the expression of inducible nitric oxide synthase (iNOS) and arginase I [6-8] and the production of nitric oxide (NO), reactive oxygen species (ROS), and peroxynitrite [5]. While MDSC have been closely linked to the inhibition of $\mathrm{T}$ cell migration, proliferation, and expression of effector molecules [9], it remains unclear the impact of MDSC on the differentiation of $\mathrm{CD} 8^{+} \mathrm{T}$ cells into effector populations and on $\mathrm{T}$ cell efficacy after ACT.

Protective anti-tumor T cell immunity, and therefore the success of $\mathrm{ACT}$, requires differentiation of $\mathrm{CD} 8^{+} \mathrm{T}$ 
cells into cytolytic and cytokine-producing effector cells [10]. Naïve undifferentiated $\mathrm{CD} 8^{+} \mathrm{CD} 44^{\text {low }} \mathrm{CD}^{2} \mathrm{~L}^{+} \mathrm{T}$ cells initially progress into $\mathrm{CD} 8{ }^{+} \mathrm{CD} 44^{\text {high }} \mathrm{CD} 62 \mathrm{~L}^{+}$central memory $\mathrm{T}$ cells $\left(\mathrm{T}_{\mathrm{CM}}\right)$, and then into $\mathrm{CD} 8^{+} \mathrm{CD} 44^{\text {high }}$ CD62 $\mathrm{L}^{-}$effector memory $\mathrm{T}$ cells $\left(\mathrm{T}_{\mathrm{EM}}\right)$ and effector $\mathrm{T}$ cells $\left(\mathrm{T}_{\mathrm{EFF}}\right)$ [11]. Paradoxically, acquisition of full effector function before ACT impairs the anti-tumor effect of $\mathrm{CD} 8^{+}$ $\mathrm{T}$ cells [12]. In fact, transfer of activated undifferentiated CD44 ${ }^{\text {low }} \mathrm{CD} 2 \mathrm{~L}^{+} \mathrm{CD}^{+} \mathrm{T}$ cells (referred as stem cell memory $\mathrm{T}$ cells $\left(\mathrm{T}_{\mathrm{SCM}}\right)$ ) into tumor-bearing mice resulted in higher anti-tumor responses, compared to those found in mice receiving $\mathrm{T}_{\mathrm{EM}}$ cells [13]. Thus, inhibition of $\mathrm{CD} 8^{+}$ $\mathrm{T}$ cell differentiation increased their efficacy after ACT.

Multiple pathways regulate the metabolically demanding process of differentiation of activated $\mathrm{CD}^{+}$ $\mathrm{T}$ cells into terminal $\mathrm{T}_{\mathrm{EM}}$ cells, including the activation of the mammalian/mechanistic target of rapamycin complex I (mTOR) [14, 15]. Among different cellular effects, mTOR regulates global protein synthesis through the phosphorylation of the translation initiation factor P70-S6K and the inactivation of the translation inhibitor eIF4E-binding protein (4E-BP1) [16]. Under favorable cellular conditions, mTOR signaling induces capdependent translation and ribosomal assembly. However, after exposure of cells to stress conditions, mTOR activity drops, allowing cells to adapt to the harsh environment [17]. Recent studies showed that the inhibition of mTOR in $\mathrm{T}$ cells enhanced their survival and anti-tumor activity after ACT [18]. However, the effect of MDSC on T cell mTOR activity and thereby on ACT remains unknown.

Here, we sought to determine the effect of MDSC in the differentiation and anti-tumor activity of $\mathrm{CD}^{+} \mathrm{T}$ cells used for ACT. Our findings indicate that transient conditioning of $\mathrm{T}$ cells with MDSC inhibits their differentiation into effector $\mathrm{T}$ cells and improves their antitumor efficacy after ACT. These effects correlated with a lower mTOR signaling, which regulated the survival of T cells after exposure to MDSC. Continuation of this research could provide beneficial implications for ACT approaches in cancer patients.

\section{RESULTS}

\section{MDSC impair the differentiation of in vitro activated $\mathrm{CD8}^{+} \mathrm{T}$ cells independently of TCR signaling}

We first sought to determine whether MDSC altered the in vitro progression of activated $\mathrm{CD}^{+} \mathrm{T}$ cells into effector populations. To test this, we monitored the expression of the differentiation markers, CD44 and CD62L, in SIINFEKL-activated $\mathrm{CD}^{+} \mathrm{T}$ cells from OT-1 mice co-cultured with tumor-MDSC or non-suppressive immature myeloid cells (iMC). The expression of CD44 increases as $\mathrm{CD}^{+} \mathrm{T}$ cells differentiate into $\mathrm{T}_{\mathrm{EFF}}$ cells, whereas CD62L levels are progressively lost [19]. An elevated percentage of undifferentiated $\mathrm{CD} 44^{\text {low }} \mathrm{CD} 2 \mathrm{~L}^{+}$ $\mathrm{CD}^{+} \mathrm{T}$ cells was found in SIINFEKL-primed OT-1 cells treated with MDSC, compared to those exposed to iMC, which progressed mainly into $\mathrm{CD} 44^{\text {high }} \mathrm{CD} 62 \mathrm{~L}^{+} \mathrm{T}_{\mathrm{CM}}$ cells (Figure 1A). Also, a similar CD44 ${ }^{\text {low }} \mathrm{CD} 2 \mathrm{~L}^{+}$arrest was observed in $\mathrm{CD}^{+} \mathrm{T}$ cells activated with anti-CD3/CD28 and co-cultured with tumor-MDSC or bone marrowderived MDSC (BM-MDSC) (Figure 1B), confirming the inhibitory effect of MDSC on $\mathrm{T}_{\mathrm{EFF}}$ differentiation. Because naïve and undifferentiated primed $\mathrm{CD} 8^{+} \mathrm{T}$ cells share the phenotype $\mathrm{CD} 44^{\text {low }} \mathrm{CD}^{2} 2 \mathrm{~L}^{+}$[11], and MDSC significantly blunted proliferation of activated $\mathrm{CD}^{+}$ T cells (Suppl. Figure 1), we studied whether MDSC blocked the activation of $\mathrm{CD}^{+} \mathrm{T}$ cells. A similar increase in the activation- $\mathrm{T}_{\mathrm{SCM}}$ markers Sca-1, CCR7, CD122, and CD127 was noted in CD44 ${ }^{\text {low }} \mathrm{CD} 6 \mathrm{~L}^{+} \mathrm{T}$ cells co-cultured with MDSC or iMC, but not in resting T cells (Figure 1C), indicating that the $\mathrm{CD} 44^{\text {low }} \mathrm{CD} 62 \mathrm{~L}^{+}$phenotype induced by MDSC was distinct from that of naïve T cells.

To further assess the effect of tumor-MDSC on early stages of $\mathrm{T}$ cell activation, we measured the expression of phospho-Zap-70 (pY319), a major kinase related with early stages of $T$ cell receptor (TCR) signaling [20]. Co-culture of $\mathrm{T}$ cells with MDSC did not impair the upregulation of phospho-Zap-70 induced upon anti-CD3/ CD28 activation (Figure 2A). In addition, equivalent levels of IL-2 and a similar induction of early activation markers CD25 and CD69 were found in control activated T cells and those co-cultured with tumor-MDSC (Figure 2B-2C), demonstrating that MDSC impaired the progression of $\mathrm{CD}^{+} \mathrm{T}$ cells into effector populations, without altering TCR-related signaling or early activation processes.

\section{Arrest on $\mathrm{CD8}^{+} \mathrm{T}$ cell differentiation by MDSC depends on permanent cell to cell contact}

We studied the need for cell to cell contact during the arrest on T cell differentiation by MDSC. An increased percentage of $\mathrm{CD} 44^{\text {low }} \mathrm{CD} 2 \mathrm{~L}^{+}$cells was found in activated $\mathrm{CD}^{+} \mathrm{T}$ cells directly co-cultured with MDSC, but not in those separated by transwells (Figure 3A), indicating that the arrest in $\mathrm{CD}^{+} \mathrm{T}$ cell differentiation induced by MDSC relies on close proximity between MDSC and T cells. This agrees with previous reports showing the close contact requirement for the $\mathrm{T}$ cell suppression mediated by MDSC-related reactive nitrogen species [21-23]. Then, we investigated whether the alterations in $\mathrm{CD}^{+} \mathrm{T}$ cell differentiation triggered by tumor-MDSC were permanent. Deletion of MDSC after 48 hours of T:MDSC co-culture restored the differentiation of $\mathrm{CD}^{+} \mathrm{T}$ cells into a CD44 ${ }^{\text {high }} \mathrm{CD} 2 \mathrm{~L}^{+}$phenotype (Figure $3 \mathrm{~B})$, suggesting that the differentiation arrest induced by MDSC was a reversible process. 
$\mathbf{A}$

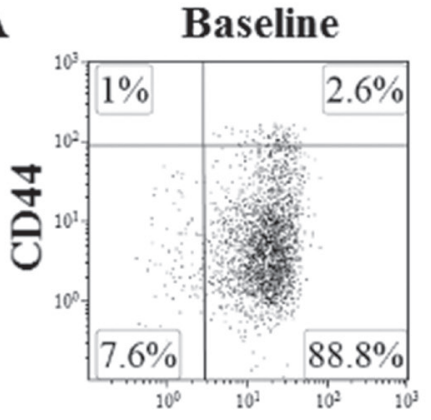

OT-1

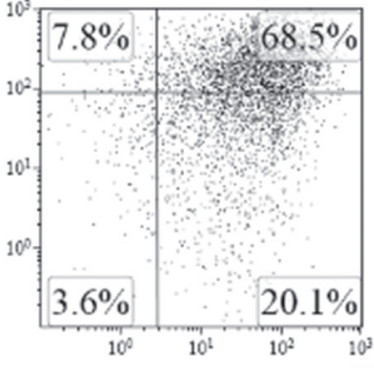

OT-1 + iMC

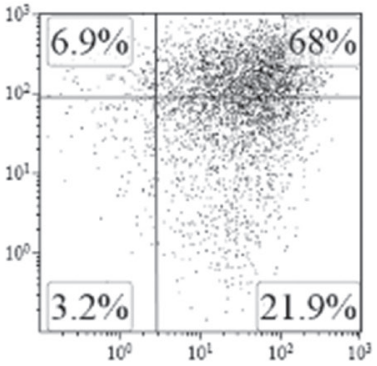

OT-1 + MDSC

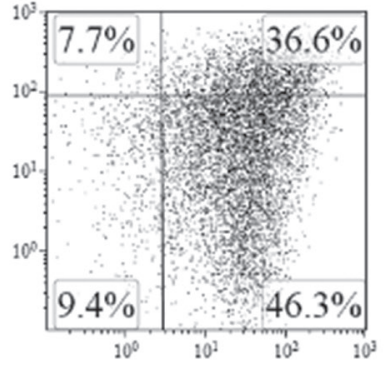

CD62L

B
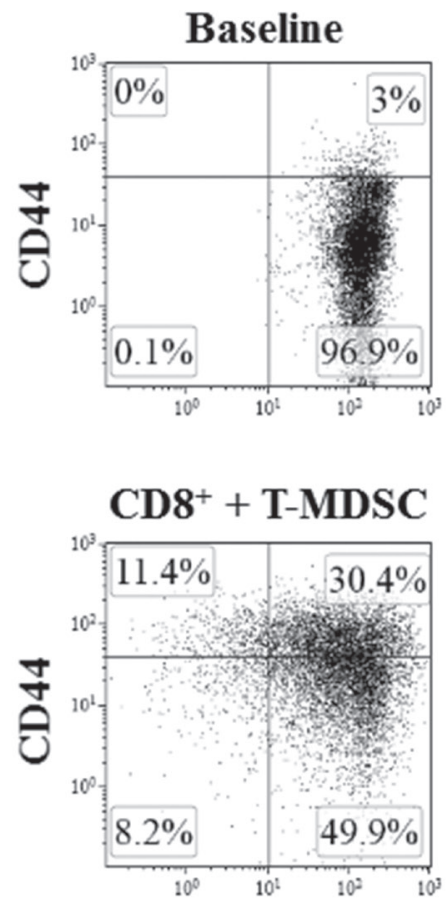
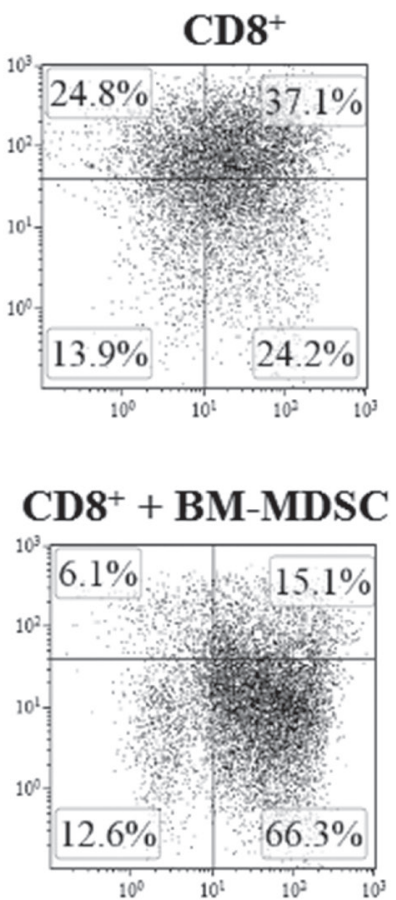
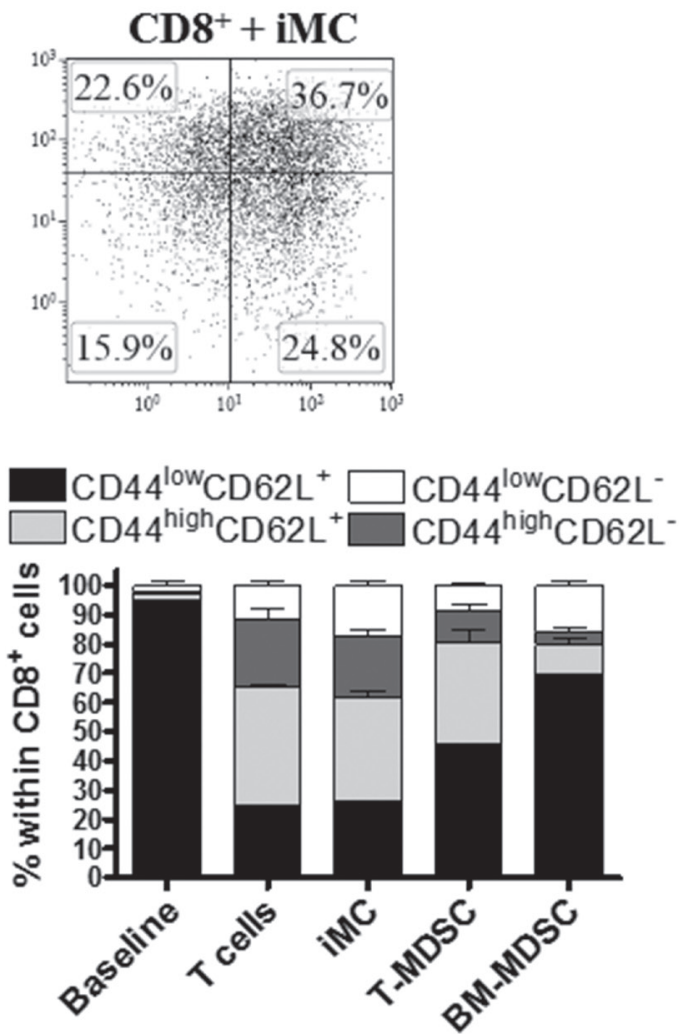

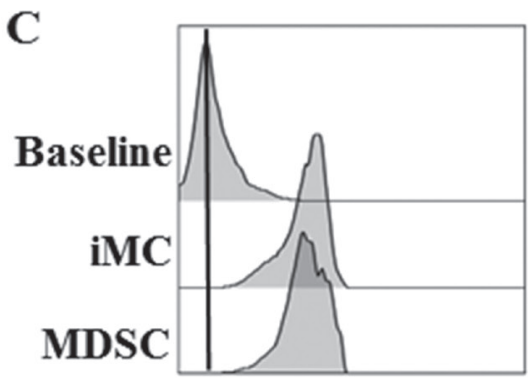

Sca1

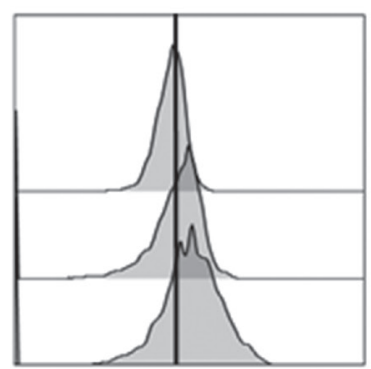

CCR7

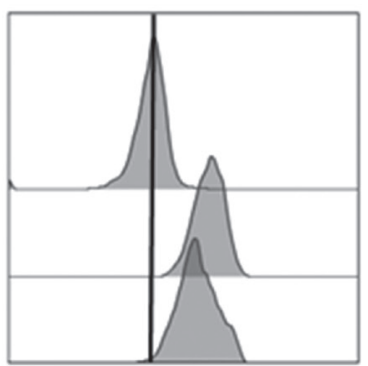

CD122

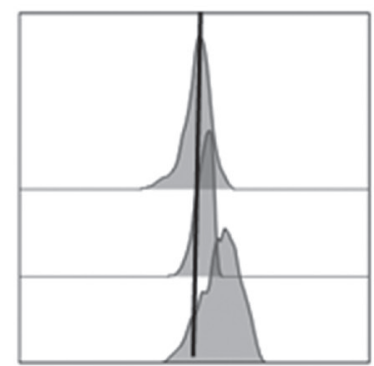

CD127

Figure 1: MDSC impairs activated $\mathbf{C D 8}^{+} \mathbf{T}$ cell differentiation. A. OT-1 cells were activated with SIINFEKL ( $\left.2 \mu \mathrm{g} / \mathrm{ml}\right)$ and cultured alone or in the presence of iMC or tumor-MDSC $(1: 1 / 2)$ for 48 hours, after which $\mathrm{CD} 8^{+} \mathrm{T}$ cells were tested by flow cytometry for the expression of CD62L and CD44. Baseline represented the non-stimulated CD8 ${ }^{+} \mathrm{T}$ cells. Dot plots are from 3 repeats. B. CD8 ${ }^{+} \mathrm{T}$ cells were stimulated with anti-CD3-CD28 and cultured alone or in the presence of iMC, BM-MDSC or tumor-MDSC. The expression of CD62L and CD44 within gated CD8 ${ }^{+} \mathrm{T}$ cells was monitored 72 hours later by flow cytometry. Bars, represent mean $+/-\mathrm{SEM}$ from 3 experiments. C. Expression of Sca1, CCR7, CD122, and CD127 was tested by flow cytometry in gated CD8 ${ }^{+} \mathrm{CD}_{4} 4^{\text {low }} \mathrm{CD} 62 \mathrm{~L}^{+}$cells from non-activated $\mathrm{T}$ cells (baseline) or activated T cells (anti-CD3-CD28) co-cultured with iMC or MDSC for 72 hours. Histograms are a representative finding from 3 separate repeats. 

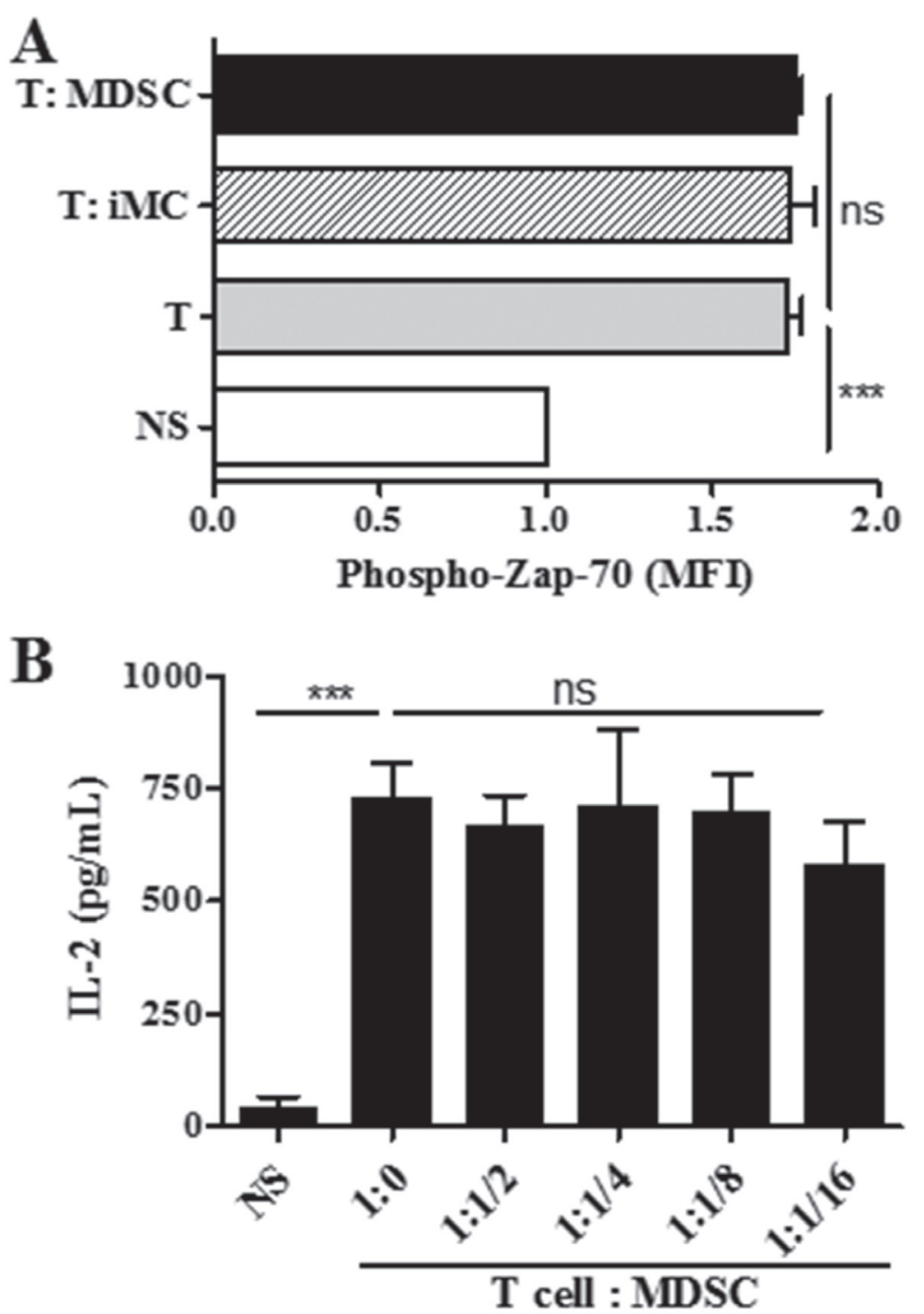

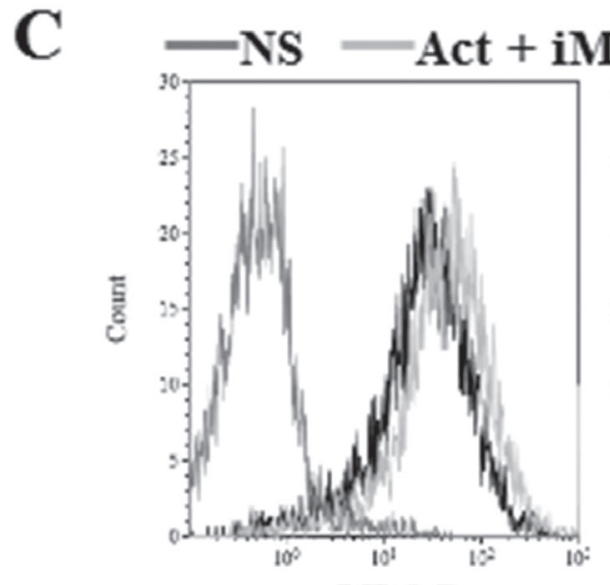

CD25

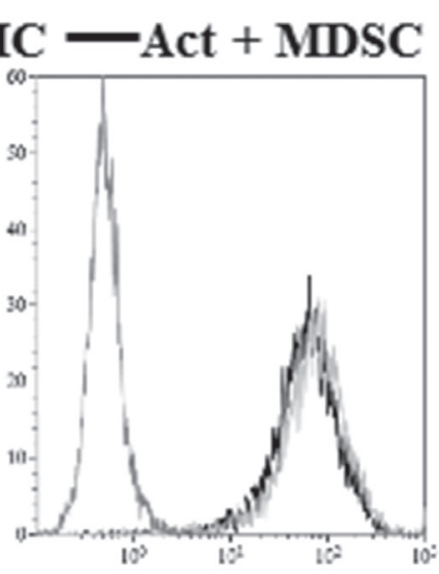

CD69

Figure 2: MDSC does not impair T cell receptor associated signaling. A. Intracellular pY319-Zap-70 levels were assessed by flow cytometry in non-stimulated (NS) or activated T cells cultured alone or in the presence of iMC or MDSC (ratio 1:1/2). Bars are mean $+/$ - SEM of mean fluorescence intensity (MFI) from 2 repeats. B. IL-2 levels measured by ELISA in supernatants from activated T cells cultured alone or in the presence of increasing MDSC numbers. Non-activated T cells (NS). Data are expressed as mean +/- SEM from 3 experiments. Expression of early activation markers CD25 and CD69 in activated T cells co-cultured for 24 hours with iMC or MDSC. Values are from 3 repeats. ${ }^{* * *} p<0.001$, ns $p>$ non-significant. 
T cells conditioned with MDSC display an increased anti-tumor efficacy after ACT and become less susceptible to MDSC upon reexposure

Transfer of $\mathrm{CD}^{2} 4^{\text {low }} \mathrm{CD} 62 \mathrm{~L}^{+} \mathrm{CD} 8^{+} \mathrm{T}$ cells into tumor-bearing mice resulted in higher anti-tumor responses [11]. Therefore, we studied whether antigenspecific $\mathrm{CD}^{+} \mathrm{T}$ cells expanded in the presence of MDSC exhibited a higher anti-tumor activity after ACT.
Splenocytes from CD45.1 $1^{+}$OT-1 mice were activated with SIINFEKL and co-cultured with MDSC or iMC for 48 hours, after which $\mathrm{CD} 8^{+} \mathrm{T}$ cells were sorted and transferred into CD45.2 $2^{+}$mice bearing s.c. EG7 tumors for 7 days. A higher anti-tumor effect was found in EG7bearing mice transferred with MDSC-conditioned $\mathrm{CD} 8^{+}$ $\mathrm{T}$ cells compared to those receiving iMC-treated $\mathrm{CD} 8^{+}$ $\mathrm{T}$ cells (Figure 4A). The increased anti-tumor efficacy induced by MDSC-educated OT-1 cells correlated with a higher IFN $\gamma$ production and an elevated frequency of the transferred $\mathrm{CD} 8^{+} \mathrm{T}$ cells in spleen and tumor (Figure 4B-

A
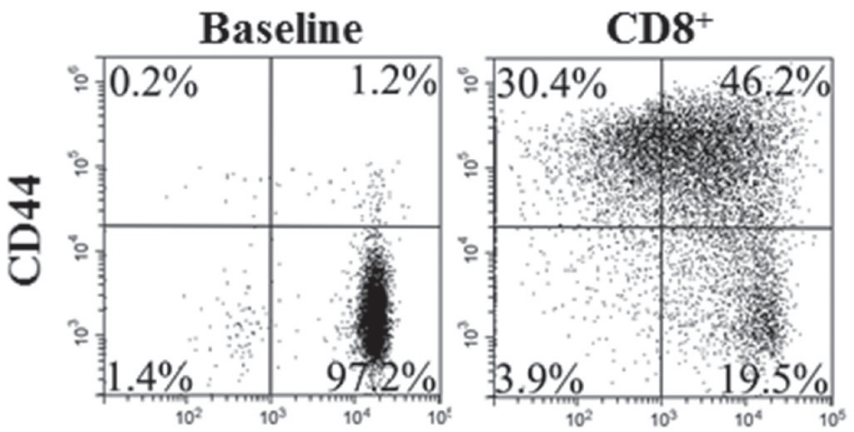

$\mathrm{CD8}^{+}+$MDSC
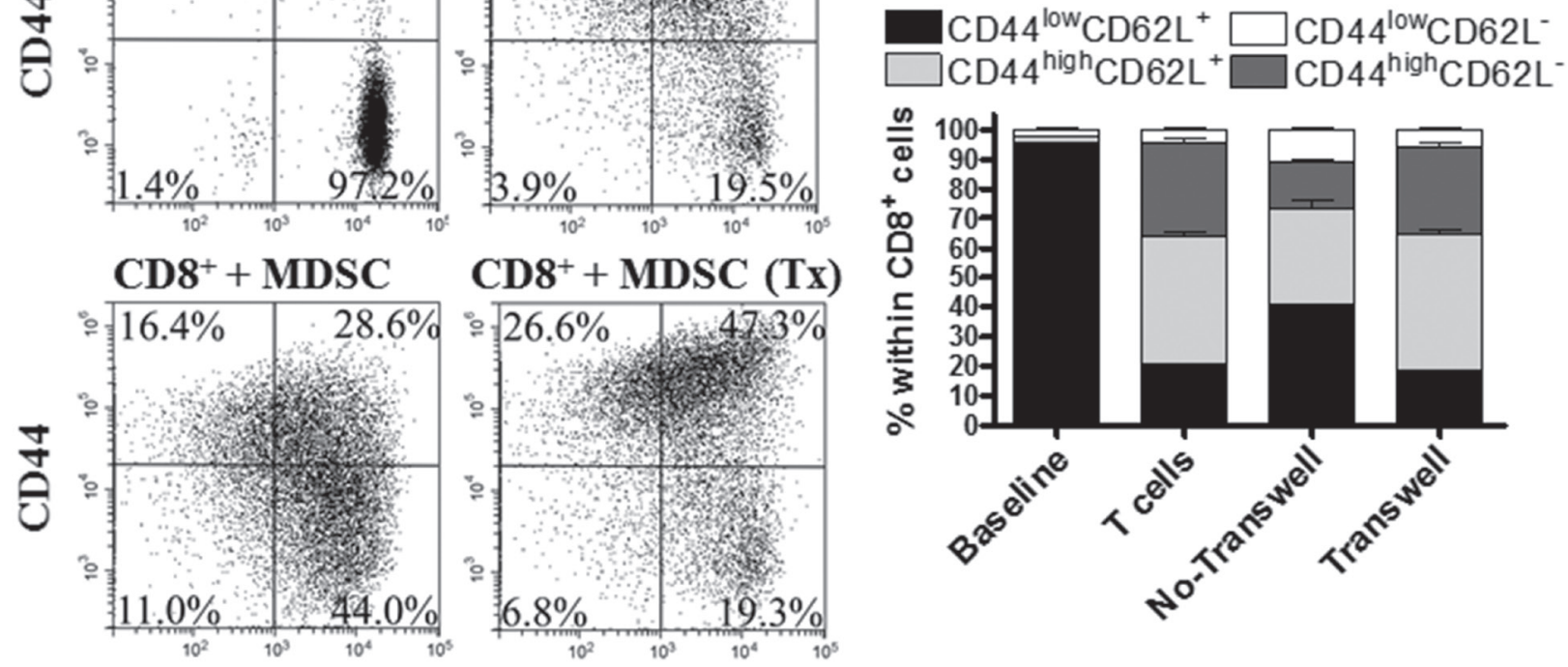

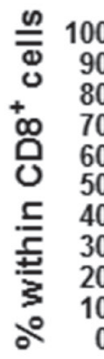

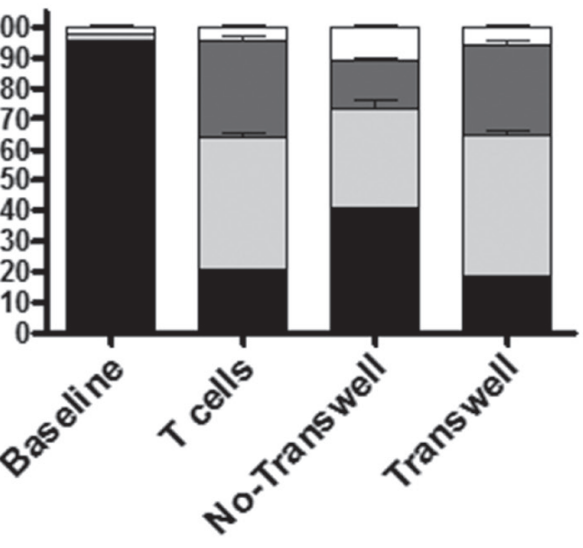

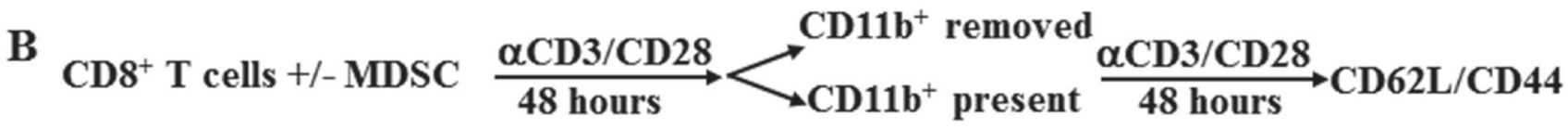
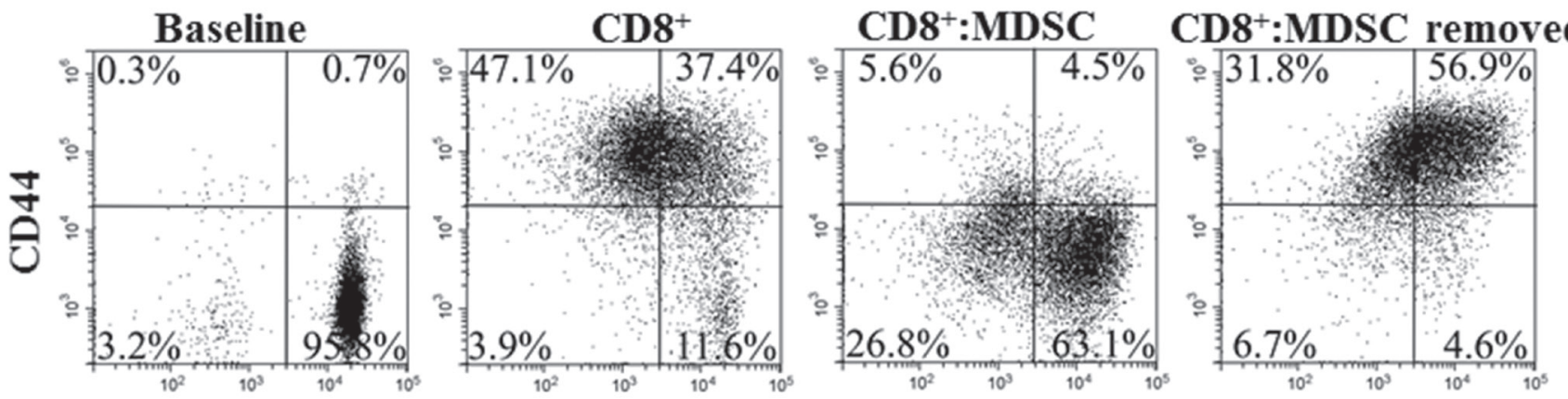

CD62L

Figure 3: MDSC impair $\mathbf{C D 8}^{+} \mathbf{T}$ cell differentiation through permanent cell to cell contact. $\mathbf{A} .1 \times 10^{6} \mathrm{CD} 8^{+} \mathrm{T}$ cells were activated with anti-CD3/CD28 and cultured with MDSC (1:1/2) using or not transwells. The levels of CD44 and CD62L were then monitored 72 hours later. Dot plots are a representation of one of 3 similar experiments. Bars represent mean $+/-$ SEM from 3 experiments. B. Activated $\mathrm{CD}^{+} \mathrm{T}$ cells were cultured alone or with tumor-MDSC for 48 hours. Then, MDSC were depleted using anti-CD $11 \mathrm{~b}$ beads and the $\mathrm{CD} 8^{+} \mathrm{T}$ cells cultured alone or with MDSC for additional 48 hours, after which the expression of CD44 and CD62L was established by flow cytometry. Figures are a representative dot plot from 3 independent and similar repeats. 


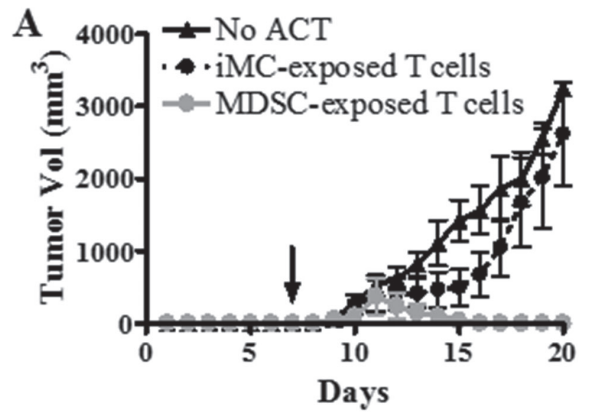

C
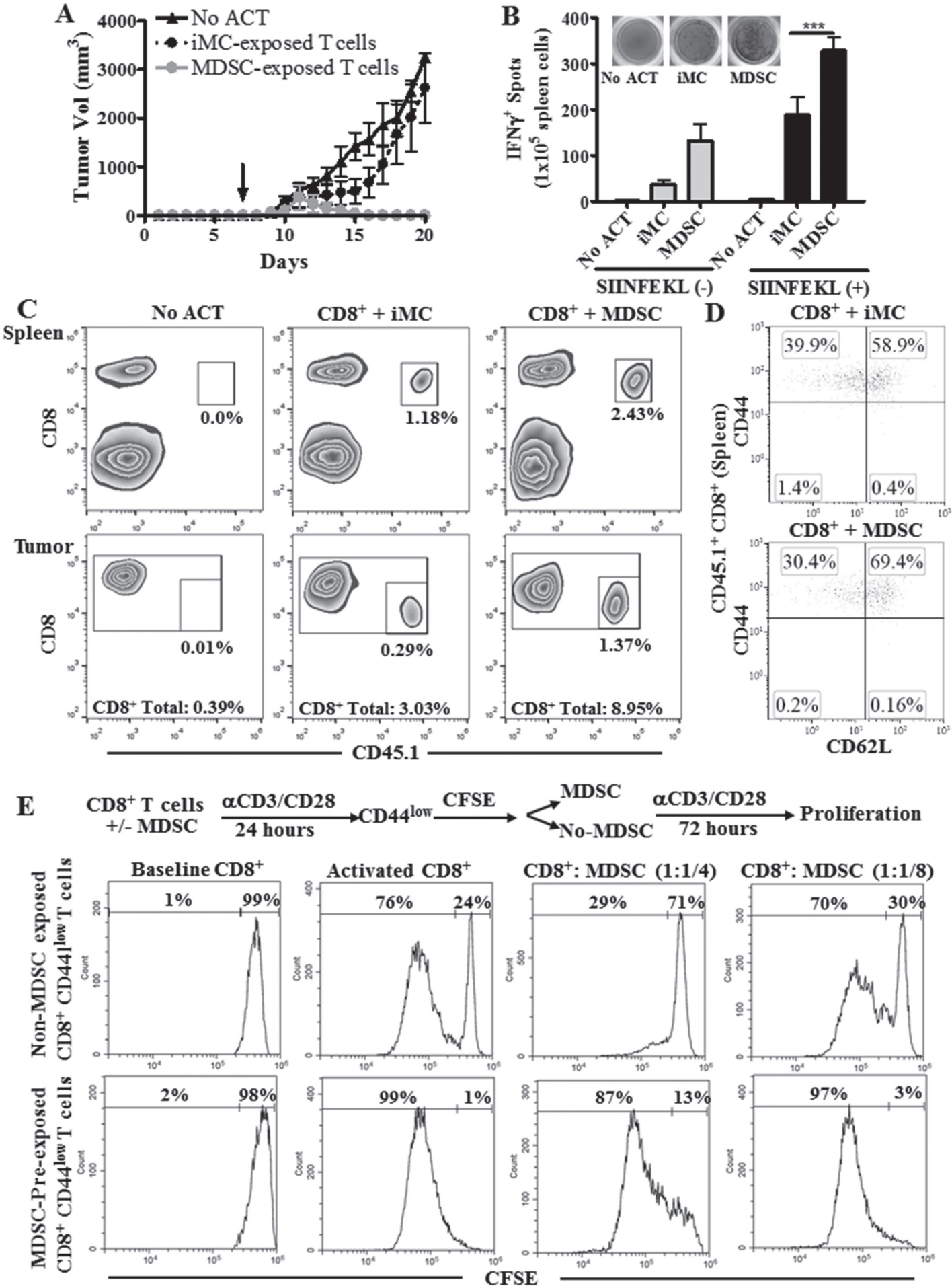

Figure 4: $T$ cells conditioned with MDSC show an increased anti-tumor efficacy after ACT. A. CD45.2+ C57BL/6 mice were injected s.c. with EG-7 cells for 7 days to develop palpable tumors. Next, mice received via tail vein $1 \times 10^{6} \mathrm{CD} 8^{+} \mathrm{CD} 45.1^{+} \mathrm{OT}-1 \mathrm{~T}$ cells activated with SIINFEKL $(2 \mu \mathrm{g} / \mathrm{mL})$ and cultured alone or in the presence of iMC or MDSC for 48 hours prior to injection. Tumor volume was then monitored until endpoint. Mice that did not receive OT-1 cells (no ACT) served as controls. $n=5$ mice per condition. $* * * p<$ 0.001 B. Fourteen days after the ACT, mice were sacrificed and the spleens from each group analyzed by Elispot for IFN $\gamma$ production upon overnight challenge with SIINFEKL. C. Spleens and tumors from mice B. were analyzed for the accumulation of CD45. $1^{+} \mathrm{CD} 8^{+}$cells. $n$ = 5 per group. D. Expression of CD62L and CD44 was monitored in the spleens of mice from B. after gating within the transferred OT-1 cells $\left(\mathrm{CD} 45.1^{+} \mathrm{CD} 8^{+}\right)$. Figures are a representative dot plot from 5 tumor-bearing mice per group. E. Activated $\mathrm{CD} 8^{+} \mathrm{T}$ cells were cultured with MDSC (1:1) for 24 hours, after which the $\mathrm{CD} 44^{\text {low }} \mathrm{CD} 8^{+} \mathrm{T}$ cells were sorted, labeled with CFSE (baseline), and cultured alone or in the presence of MDSC $(1: 1 / 4 ; 1: 1 / 8)$ for additional 72 hours. CFSE dilution was then monitored by flow cytometry. 
4C). Thus, expansion of $\mathrm{CD}^{+} \mathrm{T}$ cells in the presence of MDSC improved ACT efficacy. Next, we studied whether $\mathrm{T}$ cells pre-exposed to MDSC maintained their phenotype after transfer into EG7-bearing mice. A lower frequency of terminal $\mathrm{T}_{\mathrm{EFF}}$ CD44 ${ }^{\text {high }}$ CD62 $\mathrm{L}^{-}$cells, and a higher percentage of $\mathrm{T}_{\mathrm{CM}} \mathrm{CD} 44^{\text {high }} \mathrm{CD} 62 \mathrm{~L}^{+} \mathrm{T}$ cells were found in the transferred CD45.1 $1^{+} \mathrm{CD}^{+} \mathrm{OT}-1$ cells conditioned with MDSC, compared to those exposed to iMC (Figure 4D), suggesting that initial culture of $\mathrm{CD}^{+} \mathrm{T}$ cells with MDSC delays their differentiation into $\mathrm{T}_{\mathrm{EFF}}$ in vivo.

Next, we investigated whether the CD44 ${ }^{\text {low }} \mathrm{CD}^{+}$ $\mathrm{T}$ cells previously conditioned with MDSC became less susceptible to MDSC upon re-exposure. Thus, anti-CD3/ $\mathrm{CD} 28$ primed $\mathrm{CD}^{+} \mathrm{T}$ cells were co-cultured with or without MDSC for 24 hours, after which $\mathrm{CD} 44^{\text {low }} \mathrm{CD}^{+} \mathrm{T}$ cells were sorted, labeled with CFSE, and cultured alone or in the presence of MDSC for additional 72 hours. Initial exposure of activated CD8 ${ }^{+} \mathrm{T}$ cells to MDSC significantly increased the ability of CD $44^{\text {low }} \mathrm{CD} 8^{+} \mathrm{T}$ cells to proliferate both alone and in the presence of MDSC, compared to CD44 ${ }^{\text {low }} \mathrm{CD}^{+} \mathrm{T}$ cells initially cultured in the absence of MDSC (Figure 4E, Suppl. Figure 2). Thus, our results indicate that $\mathrm{MDSC}$-educated $\mathrm{CD} 44^{\text {low }} \mathrm{CD} 8^{+} \mathrm{T}$ cells displayed a higher proliferative potential and became less susceptible to MDSC upon re-exposure.

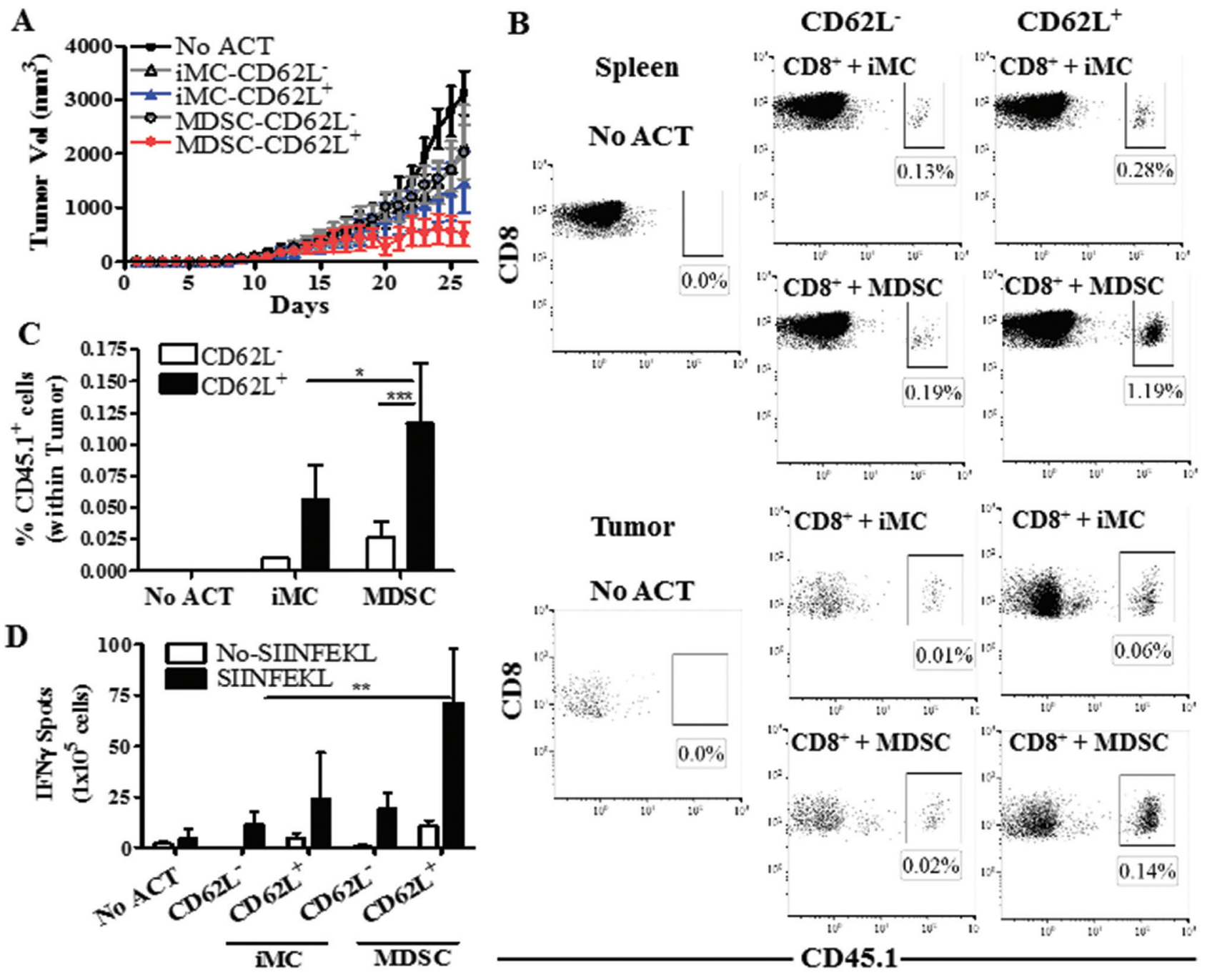

Figure 5: MDSC-conditioned $\mathbf{C D 6 2 \mathbf { L } ^ { + }} \mathbf{T}$ cells show higher anti-tumor efficacy. $\mathbf{A}$. CD45.1 $1^{+} \mathrm{CD} 8^{+}$OT-1 T cells activated with SIINFEKL $(2 \mu \mathrm{g} / \mathrm{mL})$ and cultured for 48 hours in the presence of iMC or MDSC were sorted by flow cytometry into $\mathrm{CD}^{2} \mathrm{~L}^{+}$and CD62 $\mathrm{L}^{-}$ cells. The sorted populations were then transferred (4x105/mouse) into CD45.2 $2^{+}$C57BL/6 mice bearing established EG7 tumors, after which tumor burden was measured until endpoint. Mice that did not receive OT-1 cells served as controls (No ACT). $n=5$ mice per group. B. Twelve days following the ACT, mice were sacrificed and spleens and tumors analyzed for the accumulation of the transferred CD45.1 ${ }^{+}$ $\mathrm{CD} 8^{+}$cells. Figure is a representation of results from 5 different mice. C. Quantitation of the accumulation of CD45.1 $1^{+} \mathrm{CD} 8^{+}$cells after ACT in the tumors. Data are the mean $+/$ - SEM from 3 experiments. ${ }^{* * *} p<0.001$. D. Spleens from each group were analyzed by Elispot for IFN $\gamma$ production after overnight challenge with SIINFEKL. $n=5$ mice. ${ }^{* *} p<0.01$ 


\section{Role of $\mathrm{CD}^{2} \mathrm{~L}^{+} \mathrm{T}$ cells in the anti-tumor effects induced by MDSC-educated $\mathrm{T}$ cells}

We aimed to determine whether the CD44 $\mathrm{CD}_{62} \mathrm{~L}^{+} \mathrm{T}$ cells were responsible for the enhanced antitumor effects induced by MDSC-conditioned $\mathrm{T}$ cells. However, we were limited by the low proliferation of $\mathrm{T}$ cells co-cultured with MDSC, which did not allow to sort enough numbers of $\mathrm{CD} 44^{\text {low }} \mathrm{CD} 62 \mathrm{~L}^{+} \mathrm{T}$ cells for the ACT. Alternatively, we sorted CD62 $\mathrm{L}^{-}$and $\mathrm{CD} 62 \mathrm{~L}^{+} \mathrm{T}$ cells and tested their role in the anti-tumor activity induced by MDSC-educated T cells. SIINFEKL-activated CD45.1 $1^{+}$ OT-1 cells were cultured for 48 hours with MDSC or iMC, after which $\mathrm{CD} 8^{+} \mathrm{T}$ cells were sorted by flow cytometry into $\mathrm{CD}^{2} 2 \mathrm{~L}^{+}$and $\mathrm{CD} 62 \mathrm{~L}^{-}$cells and transferred i.v. into CD $45.2^{+}$mice bearing established s.c. EG7 tumors. A significant delay in EG7 tumor growth was found in mice transferred with MDSC-treated $\mathrm{CD}^{2} 2 \mathrm{~L}^{+} \mathrm{T}$ cells, compared to those receiving MDSC-exposed $\mathrm{CD} 62 \mathrm{~L}$ counterparts or iMC-conditioned $\mathrm{T}$ cells (Figure 5A). Accordingly, transferred-CD62 $\mathrm{L}^{+} \mathrm{CD} 8^{+} \mathrm{T}$ cells expanded in the presence of MDSC showed a higher accumulation in tumor and spleen (Figure 5B-5C) and had an elevated IFN $\gamma$ production (Figure 5D), compared to the counterpart groups of transferred $\mathrm{CD} 8^{+} \mathrm{T}$ cells. Thus, our results suggest that $\mathrm{CD}^{2} 2 \mathrm{~L}^{+} \mathrm{T}$ cells were responsible for the elevated anti-tumor effects induced by MDSC-conditioned T cells.

\section{MDSC impair global translation and mTOR signaling in $T$ cells}

Inhibition of protein synthesis pathways has been shown to block the progression of $\mathrm{CD}^{+} \mathrm{T}$ cells into effector populations [18]. We asked whether MDSC could regulate de novo translation in stimulated $\mathrm{CD} 8^{+} \mathrm{T}$ cells. Using the non-radioactive method Click-iT ${ }^{\circledR}$ and $\left[{ }^{35} \mathrm{~S}\right]$ Methionine, we found that MDSC severely restricted de novo protein synthesis in primed $\mathrm{T}$ cells (Figure 6A, Suppl. Figure 3A). This effect correlated with markers of a blunted T cell-translation [24], including an arrest in the $\mathrm{G}_{0}-\mathrm{G}_{1}$ phase of the cell cycle and an inhibited expression of cyclin D3 and cdk4 (Suppl. Figure 3B-3C). Interestingly, arginase inhibition by Nor-NOHA [7] did not affect the impaired protein translation and differentiation arrest induced by MDSC on T cells (Figure 6B-6C). In contrast, inhibition of iNOS through L-NMMA completely restored de novo protein synthesis and $\mathrm{T}$ cell differentiation in activated $\mathrm{CD} 8^{+} \mathrm{T}$ cells co-cultured with MDSC, while the scavenging of peroxynitrite using MnTBAP [25] induced a partial rescue effect (Figure 6B-6C, Suppl. Figure 3A). Furthermore, treatment of $\mathrm{CD} 8^{+} \mathrm{T}$ cells with non-toxic doses of peroxynitrite or nitric oxide donor SIN-1 resulted in an arrested $\mathrm{CD} 8^{+} \mathrm{T}$ cell differentiation (Figure 6D). These results indicate a potential role of reactive nitrogen species on the $\mathrm{T}$ cell differentiation alterations induced by MDSC.

mTOR promotes de novo protein synthesis through the phosphorylation of the translation initiation inducer $\mathrm{P} 70-\mathrm{S} 6 \mathrm{~K}$ and inactivation of the translation inhibitor 4EBP1 [16]. Because MDSC impaired de novo translation in $T$ cells, we determined the potential role of a decreased mTOR signaling in this process. Using an activity method that measures the ability of mTOR to phosphorylate P70$\mathrm{S} 6 \mathrm{~K}$, we found that MDSC inhibited mTOR signaling in stimulated $\mathrm{T}$ cells to those levels found in $\mathrm{T}$ cells treated with mTOR inhibitor rapamycin (Figure 6E). In addition, a lower expression of mTOR target 4E-BP1 was found in activated T cells cultured with MDSC, compared to control stimulated T cells (Figure 6F). Furthermore, we found that inhibition of iNOS or scavenging of peroxynitrite restored mTOR activity in T cells treated with MDSC (Figure 6G), indicating a key role of reactive nitrogen species in the inhibition of T cell-mTOR by MDSC.

Overcoming mTOR inhibition in $T$ cells co-
cultured with MDSC results in $T$ cell apoptosis

To determine the effect of overcoming the mTOR inhibition in T cells co-cultured with MDSC, we aimed to silence the expression of tuberous sclerosis complex 2 (TSC2) in T cells (Figure 7A), a key negative regulator of mTOR signaling [16]. Silencing of TSC 2 enhanced mTOR activity in stimulated $\mathrm{T}$ cells cultured alone and completely restored mTOR activity in T cells co-cultured with MDSC (Figure 7B). However, we could not determine the effect of restoring mTOR signaling in the differentiation of MDSC-conditioned T cells, as TSC2 silencing in T cells co-cultured with MDSC did not restore proliferation and resulted in a significant induction of the apoptosis marker Annexin V (Figure 7C-7D). Interestingly, the increased apoptosis was not observed in $\mathrm{T}$ cells carrying a mock siRNA and co-cultured with MDSC, suggesting a key role of the inhibition of mTOR signaling in the survival of T cells exposed to MDSC. Altogether, our results indicate that conditioning of $\mathrm{T}$ cells with MDSC induces survival pathways characterized by a blunted mTOR signaling, which prevents $\mathrm{T}$ cell differentiation and increases the anti-tumor efficacy of ACT.

\section{DISCUSSION}

Protective anti-tumor $\mathrm{T}$ cell responses require the proliferation and differentiation of $\mathrm{CD}^{+} \mathrm{T}$ cells into cytotoxic populations [26]. Paradoxically, transfer of undifferentiated $\mathrm{CD} 8^{+} \mathrm{T}$ cells into tumor-bearing mice resulted in higher anti-tumor responses and an extended survival of the transferred cells [12]. Thus, we tested whether the expansion of $\mathrm{T}$ cells in the presence of MDSC altered their differentiation into cytolytic $\mathrm{T}$ cells and 
$\mathbf{A}$

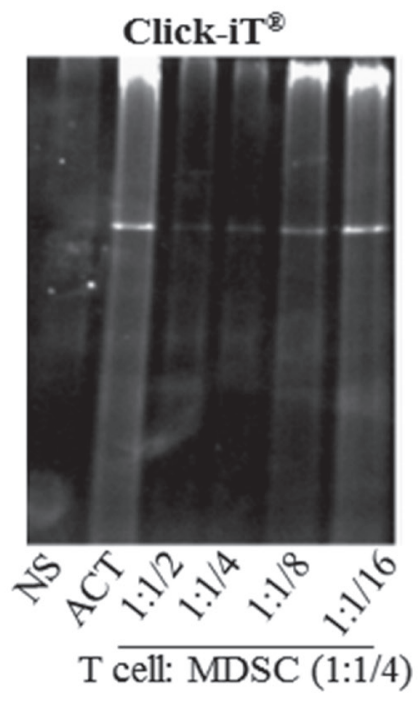

B

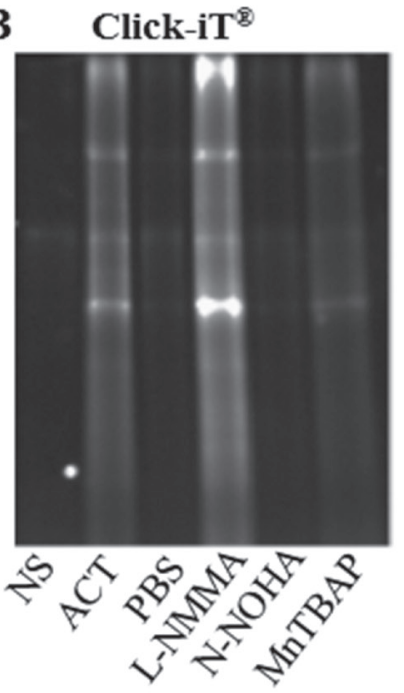

C
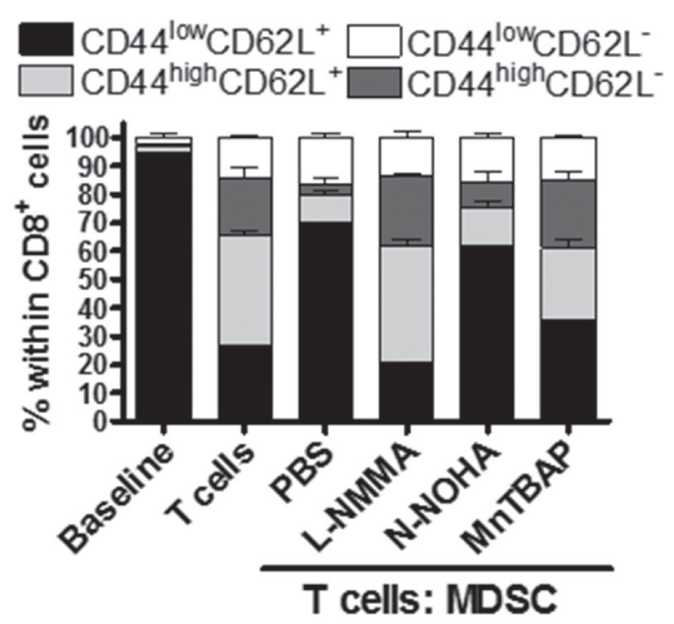

D
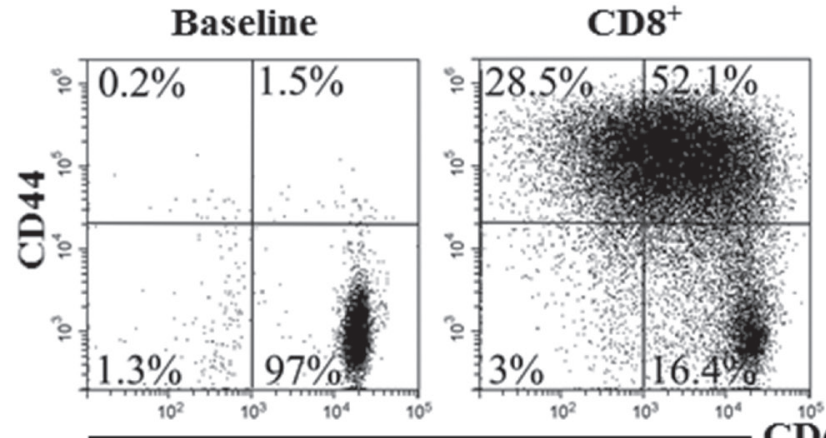

$\mathrm{CD8}^{+}+$Peroxynitrite

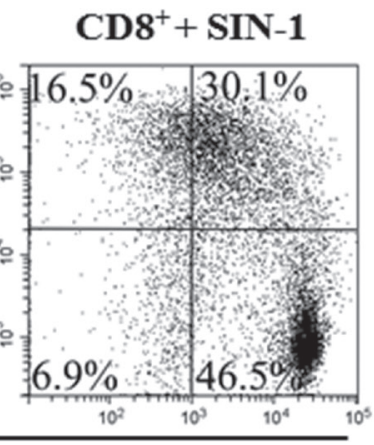

E

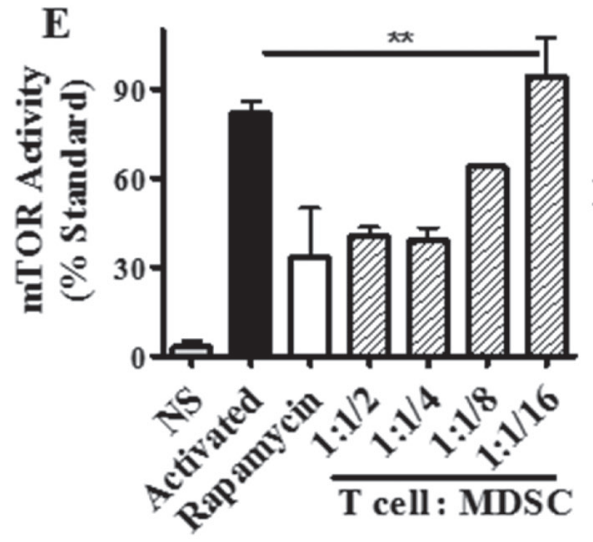

F

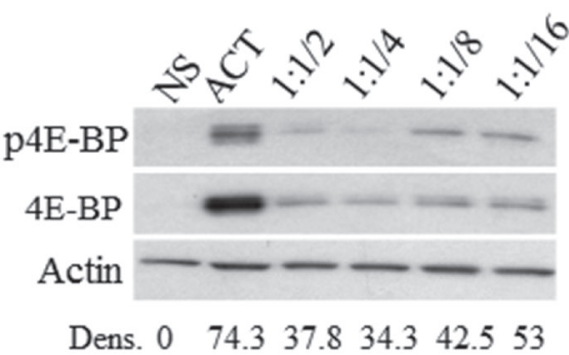

G

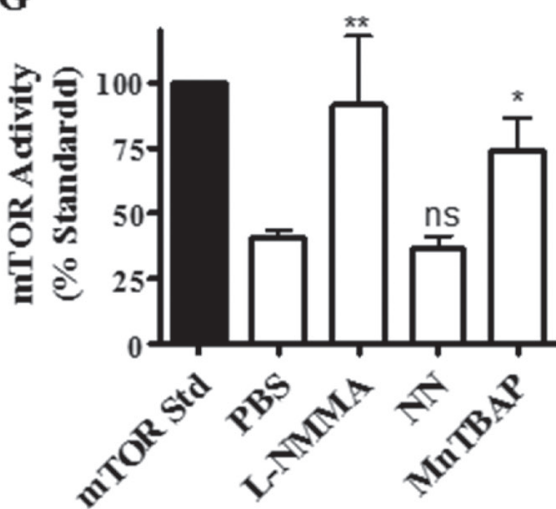

Figure 6: $T$ cells limit de novo translation and $\mathbf{m T O R}$ activity in response to MDSC. A.-B. Activated T cells were cultured alone (Act) or with increasing numbers of MDSC A., or at a fixed ratio of 4:1 (T cell : MDSC) in the presence of L-NMMA (500 $\mu$ M), N-NOHA $(200 \mu \mathrm{M})$, or MnTBAP $(100 \mu \mathrm{M})$ B. De novo protein synthesis was then monitored in T cells using Click-iT as described in the methods. NS indicates non-activated T cells. Figures are a representative result of 3 repeats. C. Activated CD $8^{+} \mathrm{T}$ cells were cultured for 72 hours in the presence of MDSC, as well as L-NMMA, N-NOHA, or MnTBAP. Then, CD62L and CD44 expression was monitored in gated $\mathrm{CD} 8^{+} \mathrm{T}$ cells by flow cytometry. Data are mean $+/-$ SEM from 3 experiments. ${ }^{* * *} p<0.001$. D. Expression of CD62L and CD44 in CD ${ }^{+} \mathrm{T}$ cells activated with anti-CD3/CD28 and cultured with peroxynitrite $(100 \mu \mathrm{M})$ or SIN-1 $(0.1 \mathrm{mM})$ for 72 hours. Results are a representative experiment of 3 repeats. E.-G. Cellular lysates from activated T cells cultured alone or in the presence of MDSC were analyzed for mTOR activity E. or the expression of phosphorylated and total 4E-BP1 F. Gray bar represents non-activated T cells (NS); black bar represents activated T cells; white bar is activated T cells cultured with rapamycin $(100 \mathrm{ng} / \mathrm{ml})$, striped bars are activated T cells co-cultured with MDSC. G. Lysates from (B) were tested for mTOR activity. Values are expressed as mean +/- SEM from 3 experiments. 
impacted their anti-tumor effects after ACT. Our results show that conditioning of $\mathrm{T}$ cells with MDSC inhibited their progression into effector populations and enhanced their ability to induce anti-tumor effects upon ACT. This surprising finding could represent a novel approach for the improvement of ACT strategies in cancer.

The traditional focus of the relationship between MDSC and T cells is that of suppression. As such, the vast body of work on the subject primarily describes the negative impact of MDSC on anti-tumor immunity and on the efficacy of cancer immunotherapies [27]. Here, we suggest the potential for MDSC-associated suppressive mechanisms to serve as a means to improve ACT through the inhibition of effector T cell differentiation. Although this approach elevated the anti-tumor activity of T cells, it remains unclear whether this transient MDSC exposure rendered $\mathrm{T}$ cells resistant to the suppressive tumor microenvironment or to the MDSC present in tumors. As such, the initial results presented in this manuscript show that conditioning of $\mathrm{CD} 8^{+} \mathrm{T}$ cells with MDSC decreased the susceptibility of $\mathrm{CD} 44^{\text {low }} \mathrm{CD}^{+} \mathrm{T}$ cells to MDSC upon re-exposure. However, further studies specifically testing the resistance of this population to MDSC in tumor-bearing mice need to be performed. Furthermore,
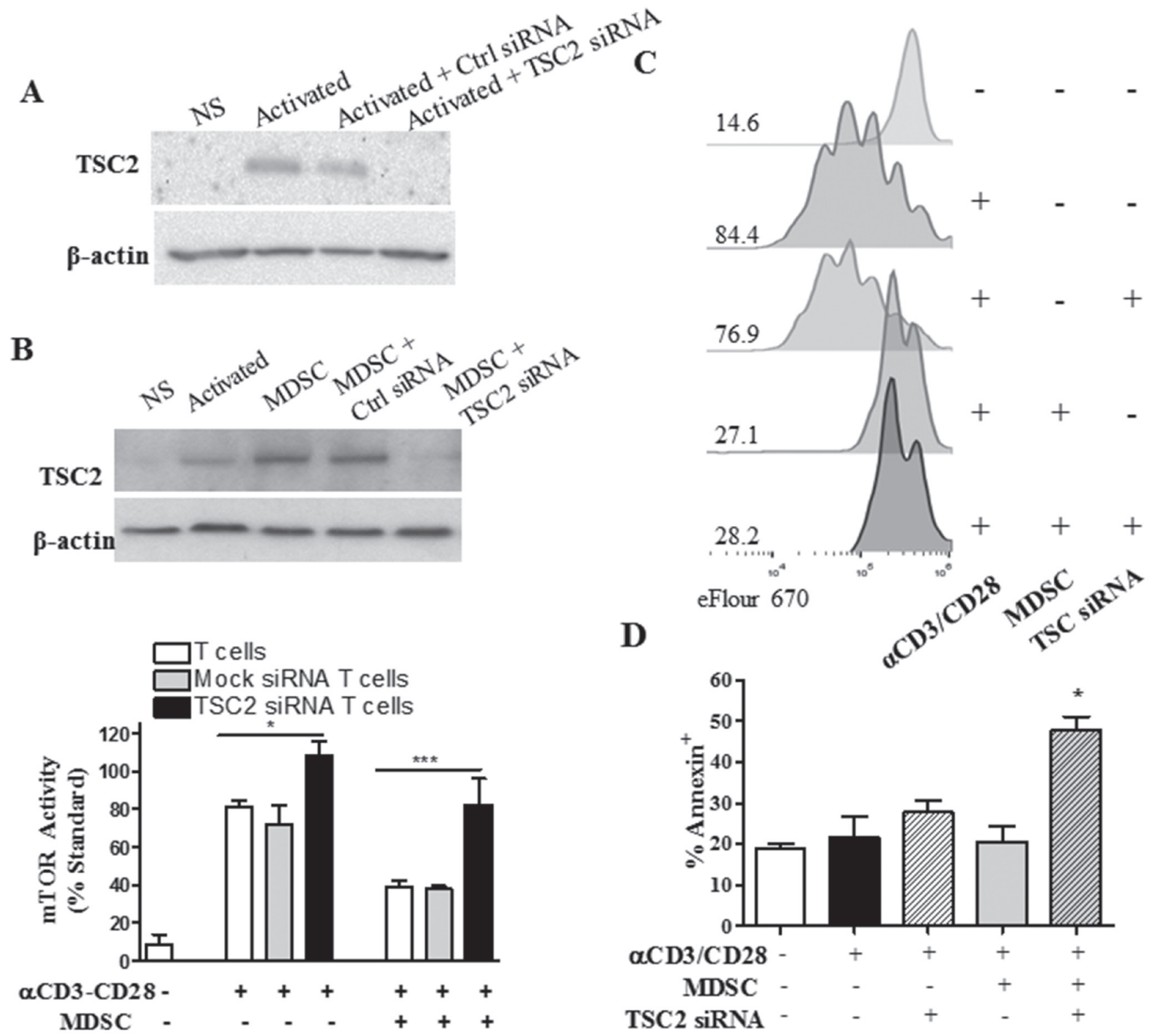

\section{D}

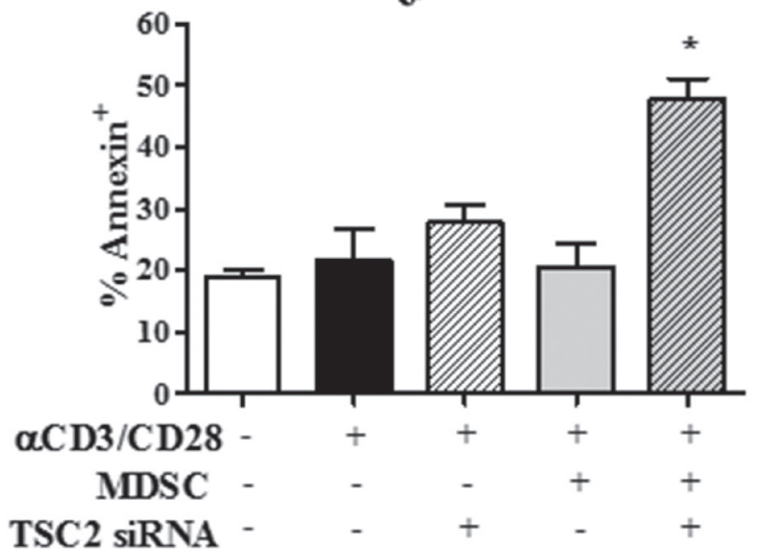

Figure 7: TSC2-silencing restores mTOR activity in T cells co-cultured with MDSC, but results in T cell apoptosis. A. A representative experiment showing the expression of TSC2 in lysates from activated T cells transfected with control or TSC2 siRNA for 72 hours. B. TSC2 expression (top) and mTOR activity (bottom) in mock and TSC2 siRNA-transfected T cells cultured with MDSC for 72 hours. C. eFluor670 dilution was analyzed by flow cytometry in activated T cells co-cultured with MDSC and/or transfected with TSC2 specific siRNA. Histogram figures are a representative result from 3 experiments. D. T cells from (B) were monitored for the expression of Annexin V by flow cytometry. All results are from a minimum of three independent repeats. 
our results together with previous publications [26, 28] indicate that the induction of transient stress pathways in $\mathrm{T}$ cells could eventually increase their ability to effectively control tumor growth. Although this effect would be hardly achieved under physiological conditions, it could represent a therapeutic opportunity to increase the efficacy of ACT approaches in cancer. In fact, transient exposure to peroxynitrite or nitric oxide donors could enable the use of this effect in therapeutic models.

Activation of the Wnt- $\beta$-catenin pathway in T cells induced a $\mathrm{T}_{\mathrm{SCM}}$ phenotype characterized by expression of CD44 ${ }^{\text {low }}$ CD 62 high $^{\text {higa }}{ }^{\text {high }}$ CD122 ${ }^{\text {high }}$ and an increased capacity to survive and self-renew in tumor-bearing mice [19]. This promotion of $\mathrm{T}_{\mathrm{SCM}}$ was also noted after treatment of acute lymphocytic choriomeningitis-infected mice with rapamycin, which significantly improved the quantity and quality of virus-specific memory $\mathrm{CD}^{+} \mathrm{T}$ cells [14]. Also, inhibition of mTOR using T cell-specific aptamers delivering mTORC1 specific siRNA or by Temsirolimus resulted in an enhanced anti-tumor effector response and vaccine-derived immunity [18, 29]. These results are in accordance with our findings indicating a potential role of the inhibition of T cell-mTOR by MDSC in the decreased differentiation of $\mathrm{CD}^{+} \mathrm{T}$ cells into effector populations. However, the specific mechanisms by which MDSC regulate $\mathrm{mTOR}$ activity remain unknown. Our data suggest a potential effect of the release of reactive nitrogen species by MDSC in the regulation of mTOR signaling in $\mathrm{T}$ cells. In fact, previous reports showed that nitrosylation of mTOR components regulates overall mTOR activity [30]. Silencing of TSC2 restored mTOR activity in T cells cultured with MDSC, but it also led to T cell apoptosis, suggesting the key role of this inhibition in the survival of $\mathrm{T}$ cells to MDSC. However, the mechanisms by which mTOR inhibition prevents cell death in T cells cocultured with MDSC remain completely unknown. Further elucidation of the pathways by which MDSC regulate mTOR in T cells may prove essential for improving $\mathrm{T}$ cell responses in future therapies and for the development of treatments to overcome the suppression of $\mathrm{T}$ cells in patients with cancer.

The notion that $\mathrm{T}$ cells are primed and ready to fight tumors, but are limited by the tumor microenvironment has been demonstrated in patients with melanoma in which lymphocytes from excised tumor masses will expand when supplemented with IL-2 [31]. Our results show that $\mathrm{T}$ cells will limit mTOR signaling as a means of coping with the suppressive effect induced by MDSC. These T cells are essentially primed, but waiting for the favorable conditions before entering the laborious metabolic process of cellular division and progression into effector cells. The idea that MDSC can promote stemness in T cells by reducing mTOR signaling is somewhat unorthodox but not unjustified, as the mTOR pathway evolved as a means of integrating multiple cellular signals. This allows mTOR to drive $T$ cell function but also to stand as sentinel during periods of stress, including changes in nutrient availability, high levels of oxidative stress, and hypoxia. In fact, while treatment with mTOR inhibitors induced $\mathrm{T}_{\mathrm{SCM}}$ phenotypes and favored anti-tumor responses in some models, it also promoted the development of MDSC, regulatory T cells (Tregs), and tolerogenic dendritic cells [32]. Moreover, rapamycin treatment prevented the protective $\mathrm{CD} 8^{+} \mathrm{T}$ cell responses induced by a human papilloma virus E7 peptide vaccine in tumor-bearing mice [33]. This effect could be induced by Tregs induced by mTOR inhibition [34].

In summary, our results show that $\mathrm{T}$ cells conditioned with MDSC show an increased antitumor activity after ACT, which correlated with a low progression of cells into effector populations and an arrest in mTOR signaling. Continuation of this research could bring beneficial implications for ACT approaches in cancer as it may demonstrate a new strategy for priming $\mathrm{T}$ cells prior to therapeutic transfer.

\section{MATERIALS AND METHODS}

\section{Animals and cell lines}

Lewis lung carcinoma (3LL) and EL-4 thymoma expressing ovalbumin (EG7) were maintained in RPMI-1640 (Lonza-Biowhittaker, Walkerville, MD) and supplemented with 10\% fetal calf serum (Hyclone, Logan, UT), 25 mM Hepes (Invitrogen, Life Technologies, Grand Island, NY), 4 mM L-glutamine (Invitrogen, Life Technologies), and $100 \mathrm{U} / \mathrm{mL}$ of penicillin, streptomycin (Invitrogen, Life Technologies). Cell lines were obtained from the American Type Culture Collection (ATCC, Manassas, VA) and periodically validated to be mycoplasma-free, using an ATCC kit. C57BL/6 mice (6-8 week-old female) were obtained from Harlan (Indianapolis, IN), C57BL/6-Tg (TcraTcrb) $1100 \mathrm{Mjb} / \mathrm{J}$ (OT-1) and CD 45.1 $1^{+}$mice from the Jackson Laboratories, and $\mathrm{CD} 45.1^{+} / \mathrm{OT}-1$ crossed in our facilities. Female C57BL6/J mice were subcutaneously (s.c.) injected with $1 \times 10^{6} 3 \mathrm{LL}$ cells. Tumor volume was determined using calipers and calculated using the formula [(small diameter $)^{2}$ x (large diameter) $x$ 0.5]. All experiments using animals were approved by the GRU-IACUC and performed following GRU animal care facility guidelines.

\section{Antibodies and reagents}

Antibodies against CD3 (clone 145-2C11), CD28 (clone 37.51), CD25 (clone PC61), CD28 (clone CD28.2), CD44 (clone IM7), and CD69 (clone H1.2F3) were obtained from Becton Dickinson Biosciences (BD Biosciences, San Jose, CA). Antibodies against Sca-1 (clone D7) CD62L (clone MEL-14), CCR7 (clone 4B12), CD122 (clone 5H4), and CD127 (clone SB/199) were 
obtained from eBioscience. Anti-phospho-4E-BP1 (clone 236B4), anti-4E-BP1 (clone 53H11), and anti-TSC2 (D93F12) antibodies were obtained from Cell Signaling Technology (Danvers, MA). Anti- $\beta$-actin antibody (clone AC-74) was obtained from Sigma-Aldrich (St. Louis, MO). Nx-hydroxy-nor-Arginine (N-NOHA), L-NGMonomethylarginine (L-NMMA), and Manganese (III) tetrakis (4-benzoic acid) porphyrin chloride (MnTBAP) were obtained from EMD Millipore (Calbiochem, Gibbstown, NJ). Induction of apoptosis was tested using annexin V Apoptosis Detection Kit (BD Biosciences). Results were expressed as the percentage of annexin $\mathrm{V}^{+}$ cells within $\mathrm{CD}^{+}$cells.

\section{Isolation of $\mathrm{T}$ cells and MDSC}

$\mathrm{CD}^{+}$and $\mathrm{CD}^{+}$cells were isolated from spleens and lymph nodes of mice using negative isolation kits (Stem Cell Technologies). Cell purity ranged between 95 and $99 \%$, as tested by flow cytometry. MDSC were isolated from tumors previously digested with DNAse and Liberase (Roche USA, Branchburg, NJ) at $37^{\circ} \mathrm{C}$ for 1 hour, as previously described [25]. Purity ranged from 90 to $99 \%$ as measured by flow cytometry. Alternatively, MDSC were generated after culturing bone marrow cells for 4 days with $20 \mathrm{ng} / \mathrm{ml} \mathrm{G-CSF}$ and GM-CSF [35], followed by sorting of GR $-1^{+}$cells. iMC were isolated from spleens of mice without tumors, as we described [25]. MDSC were depleted from T cells and MDSC cocultures by selection of $\mathrm{CD}_{11} \mathrm{~b}^{+}$cells using magnetic-bead isolation (Stemcell technologies). T cell purity ranged from $96-100 \%$ as monitored by flow cytometry.

\section{Western blot}

Cellular extracts isolated from $\mathrm{T}$ cells cultured alone or previously co-cultured with MDSC were used for protein detection by immunoblotting. Lysates were electrophoresed in $8 \%$ TrisGlycine gels, transferred to PVDF membranes, and immunoblotted against phospho4E-BP1, 4E-BP1, cyclin D3, cdk4, TSC2, or $\beta$-actin. Membrane-bound immune complexes were then detected using ECL western blot detection reagent (GE Healthcare), followed by exposure on X-ray films.

\section{Measurement of protein translation}

T cell protein translation was measured using Click$\mathrm{iT}^{\circledR}$ Labeling kit (Life Technologies). Briefly, T cells were cultured for 48 hours with or without MDSC and in the presence or the absence of specific inhibitors for arginase or iNOS, or a peroxynitrite scavenger [25]. MDSC were then removed and $\mathrm{T}$ cells starved for 1 hour of methionine, after which they were labeled for 4 hours with $50 \mu \mathrm{M}$
Click-iT $^{\circledR}$ L-azidohomoalanine. Protein lysates were harvested and normalized across samples followed by methanol/chloroform precipitation and solubilization in 1\% SDS, 50 mM Tris-HCl, pH 8.0. Proteins were treated with Click-IT ${ }^{\circledR}$ Tetramethylrhodamine analysis detection Kit and electrophoresed in 8\% TrisGlycine gels, followed by visualization through a BioRad Versadoc.

\section{Phospho-Zap70 detection}

$\mathrm{T}$ cells were activated with Dynabeads mouse T-Activator CD3/CD28 beads (Life Technologies) at a cell:bead ratio of $1: 1$, followed by addition of MDSC to the culture. Four hours later, T cells were stained with antiCD3 and anti-phospho Zap70 (Y319) antibodies using BD Phosflow kit.

\section{T cell proliferation assay}

T cell proliferation was measured, as we described [25]. For the TSC2 siRNA experiments, T cell proliferation was monitored using eFluor670 (eBioscience).

\section{siRNA Transfection of $T$ cells}

Anti-CD3/CD28-activated $\mathrm{CD}^{+} \mathrm{T}$ cells were transfected using Accell SMART pool siRNA from GE Dharmacon. Briefly, T cells were activated and cultured in a 96 well plate overnight in $100 \mu \mathrm{L}$ Accell media containing 1\% FBS and $2 \mu \mathrm{M}$ of mock or anti-TSC2 siRNA comprised of the following sequences: GCAAUGACUUUGUUUCUAU, GUGUCAUAUGAGAUUGUUC, CUCCUGUCUUUUGAUGAUA, CUAACAGCAUUAAUAUCUU. The following day, MDSC (1:1/2; T cell: MDSC) were added to the cultures and the wells supplemented with complete media for a final volume of $200 \mu \mathrm{L}$. Transfection efficiency was monitored using control siRNA labeled with 5 carboxyfluorescein (FAM) and was determined to be $>90 \%$.

\section{mTOR activity}

mTOR activity was assessed using K-LISA ${ }^{\mathrm{TM}}$ mTOR Activity Kit from EMD Millipore, according to the manufacturer's instructions. Briefly, T cell lysates were prepared in a lysis buffer comprised of $50 \mathrm{mM}$ Tris $\mathrm{HCl}, 100 \mathrm{mM} \mathrm{NaCl}, 50 \mathrm{mM} \beta$-glycerophosphate, 10\% glycerol (w/v), 1\% Tween $20(\mathrm{w} / \mathrm{v}), 1 \mathrm{mM}$ EDTA, 20 $\mathrm{nM}$ microcystin-LR, $25 \mathrm{mM} \mathrm{NaF}$, and protease inhibitor cocktail Set III. Values were normalized to the maximum mTOR standard, while T cells treated with rapamycin (100 $\mathrm{ng} / \mathrm{ml}$ ) acted as the control for mTOR activity inhibition. 


\section{Statistical analysis}

Statistical analyses were carried in GraphPad Prism. Tests were conducted at 5\% significance level. Experimental group differences of endpoints were assessed by ANOVA, whereas mean comparisons were carried out with the Tukey procedure or with the Dunnet procedure for comparisons with controls.

\section{ACKNOWLEDGMENTS}

We would like to that Claudia Hernandez, BS, for the technical support during this work.

\section{CONFLICTS OF INTEREST}

We have no conflicts of interest to disclose.

\section{GRANT SUPPORT}

This work was partially supported by National Institutes of Health (NIH) R01CA184185 to P.C.R.

\section{REFERENCES}

1. Coulie PG, Van den Eynde BJ, van der BP and Boon T. Tumour antigens recognized by $\mathrm{T}$ lymphocytes: at the core of cancer immunotherapy. NatRevCancer. 2014; 14:135146.

2. Kalos $\mathrm{M}$ and June $\mathrm{CH}$. Adoptive $\mathrm{T}$ cell transfer for cancer immunotherapy in the era of synthetic biology. Immunity. 2013; 39:49-60.

3. Restifo NP, Dudley ME and Rosenberg SA. Adoptive immunotherapy for cancer: harnessing the $\mathrm{T}$ cell response. NatRevImmunol. 2012; 12:269-281.

4. Raber P, Ochoa AC and Rodriguez PC. Metabolism of L-arginine by myeloid-derived suppressor cells in cancer: mechanisms of $\mathrm{T}$ cell suppression and therapeutic perspectives. Immunol Invest. 2012; 41:614-634.

5. Talmadge JE and Gabrilovich DI. History of myeloidderived suppressor cells. NatRevCancer. 2013; 13:739-752.

6. Rodriguez PC, Ernstoff MS, Hernandez C, Atkins M, Zabaleta J, Sierra R and Ochoa AC. Arginase I-producing myeloid-derived suppressor cells in renal cell carcinoma are a subpopulation of activated granulocytes. Cancer Res. 2009; 69:1553-1560.

7. Rodriguez PC, Quiceno DG, Zabaleta J, Ortiz B, Zea AH, Piazuelo MB, Delgado A, Correa P, Brayer J, Sotomayor EM, Antonia S, Ochoa JB and Ochoa AC. Arginase I production in the tumor microenvironment by mature myeloid cells inhibits T-cell receptor expression and antigen-specific T-cell responses. Cancer Res. 2004; 64:5839-5849.

8. Srivastava MK, Sinha P, Clements VK, Rodriguez P and
Ostrand-Rosenberg S. Myeloid-derived suppressor cells inhibit T-cell activation by depleting cystine and cysteine. Cancer Res. 2010; 70:68-77.

9. Gabrilovich DI and Nagaraj S. Myeloid-derived suppressor cells as regulators of the immune system. NatRevImmunol. 2009; 9:162-174.

10. Rosenberg SA and Restifo NP. Adoptive cell transfer as personalized immunotherapy for human cancer. Science. 2015; 348:62-68.

11. Gattinoni L, Klebanoff CA and Restifo NP. Paths to stemness: building the ultimate antitumour $\mathrm{T}$ cell. NatRevCancer. 2012; 12:671-684.

12. Gattinoni L, Klebanoff CA, Palmer DC, Wrzesinski C, Kerstann K, Yu Z, Finkelstein SE, Theoret MR, Rosenberg SA and Restifo NP. Acquisition of full effector function in vitro paradoxically impairs the in vivo antitumor efficacy of adoptively transferred CD8+ T cells. JClinInvest. 2005; 115:1616-1626.

13. Gattinoni L, Lugli E, Ji Y, Pos Z, Paulos CM, Quigley MF, Almeida JR, Gostick E, Yu Z, Carpenito C, Wang E, Douek DC, Price DA, June CH, Marincola FM, Roederer $\mathrm{M}$, et al. A human memory T cell subset with stem cell-like properties. NatMed. 2011; 17:1290-1297.

14. Araki K, Turner AP, Shaffer VO, Gangappa S, Keller SA, Bachmann MF, Larsen CP and Ahmed R. mTOR regulates memory CD8 T-cell differentiation. Nature. 2009; 460:108112.

15. Li Q, Rao RR, Araki K, Pollizzi K, Odunsi K, Powell JD and Shrikant PA. A central role for mTOR kinase in homeostatic proliferation induced CD8+ T cell memory and tumor immunity. Immunity. 2011; 34:541-553.

16. Powell JD, Pollizzi KN, Heikamp EB and Horton MR. Regulation of immune responses by mTOR. AnnuRevImmunol. 2012; 30:39-68.

17. Pearce EL, Poffenberger MC, Chang CH and Jones RG. Fueling immunity: insights into metabolism and lymphocyte function. Science. 2013; 342:1242454.

18. Berezhnoy A, Castro I, Levay A, Malek TR and Gilboa E. Aptamer-targeted inhibition of mTOR in T cells enhances antitumor immunity. JClinInvest. 2014; 124:188-197.

19. Gattinoni L, Zhong XS, Palmer DC, Ji Y, Hinrichs CS, Yu Z, Wrzesinski C, Boni A, Cassard L, Garvin LM, Paulos CM, Muranski $\mathrm{P}$ and Restifo NP. Wnt signaling arrests effector $\mathrm{T}$ cell differentiation and generates CD8+ memory stem cells. NatMed. 2009; 15:808-813.

20. Brownlie RJ and Zamoyska R. T cell receptor signalling networks: branched, diversified and bounded. NatRevImmunol. 2013; 13:257-269.

21. Apolloni E, Bronte V, Mazzoni A, Serafini P, Cabrelle A, Segal DM, Young HA and Zanovello P. Immortalized myeloid suppressor cells trigger apoptosis in antigenactivated T lymphocytes. JImmunol. 2000; 165:6723-6730.

22. Mazzoni A, Bronte V, Visintin A, Spitzer JH, Apolloni E, Serafini P, Zanovello P and Segal DM. Myeloid suppressor 
lines inhibit $\mathrm{T}$ cell responses by an NO-dependent mechanism. JImmunol. 2002; 168:689-695.

23. Bronte V, Apolloni E, Cabrelle A, Ronca R, Serafini P, Zamboni P, Restifo NP and Zanovello P. Identification of a CD11b $(+) / \mathrm{Gr}-1(+) / \mathrm{CD} 31(+)$ myeloid progenitor capable of activating or suppressing CD8(+) T cells. Blood. 2000; 96:3838-3846.

24. Rodriguez PC, Quiceno DG and Ochoa AC. L-arginine availability regulates T-lymphocyte cell-cycle progression. Blood. 2007; 109:1568-1573.

25. Raber PL, Thevenot P, Sierra R, Wyczechowska D, Halle D, Ramirez ME, Ochoa AC, Fletcher M, Velasco C, Wilk A, Reiss K and Rodriguez PC. Subpopulations of myeloidderived suppressor cells impair $\mathrm{T}$ cell responses through independent nitric oxide-related pathways. IntJCancer. 2014; 134:2853-2864.

26. Gattinoni L and Restifo NP. Moving T memory stem cells to the clinic. Blood. 2013; 121:567-568.

27. Nagaraj S, Youn JI and Gabrilovich DI. Reciprocal relationship between myeloid-derived suppressor cells and T cells. JImmunol. 2013; 191:17-23.

28. Gattinoni L, Powell DJ, Jr., Rosenberg SA and Restifo NP. Adoptive immunotherapy for cancer: building on success. NatRevImmunol. 2006; 6:383-393.

29. Wang Y, Wang XY, Subjeck JR, Shrikant PA and Kim HL. Temsirolimus, an mTOR inhibitor, enhances anti-tumour effects of heat shock protein cancer vaccines. Br J Cancer. 2011; 104:643-652.
30. Lopez-Rivera E, Jayaraman P, Parikh F, Davies MA, Ekmekcioglu S, Izadmehr S, Milton DR, Chipuk JE, Grimm EA, Estrada Y, Aguirre-Ghiso J and Sikora AG. Inducible nitric oxide synthase drives mTOR pathway activation and proliferation of human melanoma by reversible nitrosylation of TSC2. Cancer Res. 2014; 74:1067-1078.

31. Dudley ME, Wunderlich JR, Shelton TE, Even J and Rosenberg SA. Generation of tumor-infiltrating lymphocyte cultures for use in adoptive transfer therapy for melanoma patients. J Immunother. 2003; 26:332-342.

32. Powell JD, Pollizzi KN, Heikamp EB and Horton MR. Regulation of immune responses by mTOR. Annu Rev Immunol. 2012; 30:39-68.

33. Chaoul N, Fayolle C, Desrues B, Oberkampf M, Tang A, Ladant D and Leclerc C. Rapamycin Impairs Antitumor CD8+ T-cell Responses and Vaccine-Induced Tumor Eradication. Cancer Res. 2015; 75:3279-3291.

34. Wang Y, Sparwasser T, Figlin R and Kim HL. Foxp3+ $\mathrm{T}$ cells inhibit antitumor immune memory modulated by mTOR inhibition. Cancer Res. 2014; 74:2217-2228.

35. Thevenot PT, Sierra RA, Raber PL, Al-Khami AA, Trillo-Tinoco J, Zarreii P, Ochoa AC, Cui Y, Del VL and Rodriguez PC. The stress-response sensor chop regulates the function and accumulation of myeloid-derived suppressor cells in tumors. Immunity. 2014; 41:389-401. 